$\left.\int \begin{array}{c}\text { Jurnal Penelitian dan Evaluasi Pendidikan } \\ \text { Volume 23, No 1, June 2019 (26-35) }\end{array}\right)$

\title{
AN EVALUATION ANALYSIS OF STUDENTS' ATTITUDE TOWARDS PHYSICS LEARNING AT SENIOR HIGH SCHOOL
}

\author{
Dwi Agus Kurniawan \\ Universitas Jambi \\ Astalini \\ Universitas Jambi \\ Deti Kurnia Sari \\ Universitas Jambi
}

\begin{abstract}
This research is about students' attitude analysis towards Physics learning conducted at senior high schools in Batanghari Regency. The purpose of this research is to know and evaluate students' attitude toward Physics learning. This study is quantitative research employing Survey Research Design strengthened by the result of an interview to support quantitative data. This research involved 926 students of state senior high school in Batanghari. The instruments used by the researchers were in the form of questionnaires consisting of 54 items of statements by using 5-scale Likert. The results of this research show that students' attitude is at good category and quite good based on the indicators used to investigate the attitude.
\end{abstract}

Keywords: attitude, social implication, investigation, scientific attitude, interest

Permalink/DOI: http://dx.doi.org/10.21831/pep.v23i1.20821

Contact Dwi Agus Kurniawan

dwiagus.k@unja.ac.id

Department of Physics Education, Faculty of Education and Teacher Training, Universitas Jambi Kampus Pinang Masak, Jl. Raya Jambi-Ma. Bulian Km. 15, Mendalo Darat, 36361, Jambi, Indonesia 


\section{Introduction}

Education is a pivotal activity in the learning process. Developing the students' potency so that they can think critically and creatively is one of the educational goals in Indonesia (Law of Republic of Indonesia No. 20 of 2003). Giving education maximally to the students will create high-quality students. Education is known as the process of obtaining and training the skill done by the students (Wood, 2011, p. 4). In education, learning activity is one of the important factors in influencing the result of learning.

The relation of learning implication that has achievement at three areas such as cognitive, affective, and psychomotor is not apart from the assessment which must be conducted by teachers after the learning process (Riscaputantri \& Wening, 2018, p. 233). Education in Indonesia is categorized into some levels, and one of the higher educational levels in Indonesia is senior high school. In the level of senior high school, students learn a various field of knowledge; one of them is science. Physics is one subject which becomes part of science in senior high school level. Physics is considered essential to be taught as a separate subject because it gives provision of knowledge to the students. Furthermore, Kaniawati, Samsudin, Hasopa, Sutrisno, and Suhendi (2016, p. 1) state that Physics is a branch of scientific knowledge which can explain each natural phenomenon in daily life.

Physics is an abstract subject until it needs high order thinking skill which causes the students difficult in understanding Physics topics. The difficulty encountered by the students in comprehending Physics during school time causes deeper difficulty when they are at college (Guido, 2013, p. 2089). In spite of the abstract characteristic, students' internal factor like the attitude towards Physics subject is also one of the difficulties occurs in Physics learning as known that this attitude refers to the behavior and emotions of someone (Martin \& Briggs, 1986, p. 2). Attitude will be seen during the learning process. Furthermore, Fatonah (2014) explains that attitude is the tendency to act, achieve, think, and feel in facing objects, ideas, situation, and values. By knowing students' attitude in learning gives a positive effect on the improvement of learning achievement.

Nordin and Ling (2011) argue that students' attitude is the key to achieving success in the mastery and achievement improvement of the students. If the students have a positive attitude towards a certain learning process, it will give a big impact on the learning itself. Veloo, Nor, and Khalid (2015) explain that the students who have a positive attitude towards learning, it can improve their learning achievement. Likewise, students' attitude towards Physics; if the students have a positive attitude towards Physics learning, then their Physics achievement or science achievement will improve too. Students' positive attitude towards Physics occurs when the students can understand deeper about the concept of Physics and make the learning more effective in their environment. Students' negative attitude in Physics learning causes students' achievement becomes bad. Erdemir (2009) explains that good or bad Physics learning achievement is influenced by students' attitude during the learning process. If the students have a negative attitude towards Physics learning, it will make the present learning, and future learning in Physics will be more difficult. Students' attitude towards Physics can be known by identifying the social indicators of Physics, attitude towards investigation in Physics, adoption of scientific attitude, and interest to enhance the duration of learning Physics.

The social implication of Physics learning, which relates to the natural phenomenon, affects social life. As a result of science and technology development, it will generate some advantages and social impacts that will occur. It can be in the form of attitude towards social advantages, progress case, and scientific research (Welch, 2010). In the learning at school, the social implication of Physics can be seen in how students' independency and teamwork in the group. Students can be active and motivated 
during the learning process if they are demanded to share information, work collaboratively in a group, and respect other people (Yance, Ramli, \& Mufit, 2013). The form of students' independency can be seen from their completed assignment or homework given by the teacher and believe in their own abilities and cooperative attitude. Students' social ability will be more prominent when working collaboratively than working individually (Iwan \& Sani, 2015). Beside the social implication of Physics, the attitude towards investigation in Physics also affects the learning of Physics.

The attitude towards investigation in Physics is the students' point of view or actions in solving the problem occurs in Physics. Lederman, Lederman, and Antink (2013) insist that investigation refers to the combination of a scientific process with knowledge and scientific reasoning and critical thinking. Investigation in Physics can be seen on how the students solve the problem happens in the class. Welch (2010) believes that there are some ways of solving the scientific problem; they are; measuring, identifying, and experimenting in its scientific scale to find accurate information. One of the investigation activities in Physics conducted by the students is experimenting. In addition, Moeed (2013) argues that experiments conducted by students can develop their belief during their time at school that to obtain conclusion then it requires the steps that must be followed in a scientific method to know the result of new knowledge. Students' attitude in Physics investigation helps to improve students' activeness in learning. Students' activeness in learning correlates with the scientific attitude owned by the students.

Scientific attitude is a crucial attitude to be acquired. Ali et al. (2012) explain that in the educational world, especially in the world of science, a scientific attitude is a pivotal aspect because this attitude can improve good learning achievement. By nurturing a positive scientific attitude in the students, they will experience learning achievement improvement (Chiappetta, Koballa, \& Collette, 1998). In addition, by owning a sci- entific attitude, the students can think rationally and critically. Complicated and abstract learning of Physics truly needs the students to behave scientifically. Students with high scientific attitude will have a positive attitude towards Physics. Scientific attitude can be described as the expression or reaction shown in accordance with the ethics of science (Pitafi \& Farooq, 2012). The importance of having a scientific attitude for a student is to obtain knowledge from various fields of discipline (Osman, Iksan, \& Halim, 2007). In order to obtain knowledge from various fields of knowledge and especially in Physics learning, it requires students' interest to extend the duration of Physics learning.

Students' interest in extending the duration of Physics learning is influenced by themselves. Students' attitude towards science learning refers to their happy feeling or interest in it (Agunbiade, Ngcoza, Jawahar, \& Sewry, 2017). The students who consider Physics is difficult because they are not interested in extending the duration of learning Physics. The students who are interested in extending the time for learning Physics will influence their achievement, learning results, and career in Physics (Bybee, McCrae, \& Laurie, 2009). Students' interest in extending the time for learning Physics can be seen from their achievement in the field of science or Physics. One of the factors which cause students' failure in Physics learning achievement is the lack of interest in extending the amount of time for learning Physics (Visser, 2007). Therefore, more frequent the students extend their time for learning, then the better their scores or achievements will be. Thus, students' interest in extending the amount of time for learning Physics is vital to achieve good learning results.

The purpose of this research is to know students' attitude towards Physics learning at senior high schools, especially at senior high schools in Batanghari Regency. The attitude indicators are used to identify students' attitude towards Physics learning encompassing the social implication of Physics, attitude towards investigation in Physics, adoption from scientific attitude, and the in- 
terest in extending the amount of time in learning Physics. The findings of this research can contribute to improving students' attitude towards Physics learning. This research is pivotal to conducted, especially at senior high school level because attitude can influence learning results or achievement.

\section{Research Method}

The research design used in this research was survey research. This survey research design is the design which is used to collect data of questionnaires spread to some samples or to all population used to describe the attitude, opinion, behavior, or particular traits of the population (Creswell, 2012). The research samples were in the amount of 926 students. The samples were designed and determined in line with the selection of the sample through purposive sampling technique.

\section{Research Sample}

The samples of this research were five schools located at Batanghari Regency; they are State Senior High School 10 Batanghari, State Senior High School 5 Batanghari, State Senior High School 8 Batanghari, State Senior High School 1 Batanghari, and State Senior High School 6 Batanghari. Total samples consisted of grade X, XI, and XII at each school. The total number of male students were 353 people $(38.12 \%)$; the total number of female students were 573 people $(61.7 \%)$.

\section{Instruments and Procedures}

Instruments and procedures in this research were in the form of questionnaires and interview. The indicators used in this research can be seen in Table 1 .

Table 1. Indicators of Students' Attitude Questionnaire in Learning Physics

\begin{tabular}{cl}
\hline No & \multicolumn{1}{c}{ Attitude Indicators } \\
\hline 1 & Social Implication of Physics \\
2 & Attitude Towards Investigation in Physics \\
3 & Adoption of Scientific Attitude \\
4 & The Interest of Extending The Amount \\
& of Time for Learning Physics \\
\hline
\end{tabular}

The questionnaires contained four indicators. Then, during the interview, the question items are arranged referring to those indicators. The questionnaires instrument contained 54 items by using 5 -scale Likert (consisting of: 1-really disagree, 2-disagree, 3-neutral, 4-agree, and 5-really agree). The questionnaires were given to 926 students. The interview instrument was in the form of questions which were given to 35 students.

\section{Data Analysis}

Data analysis employed in this research was quantitative data analysis by using SPSS program to find out descriptive statistics. Data in this research used quantitative data analysis by using SPSS program to find out descriptive statistics. Descriptive statistics is a description or presentation of data in a big number, consisting of modus, mean, median, minimum, maximum, and standard of deviation (Cohen, Manion, \& Morrison, 2007). Then, the analysis was continued with an interview for strengthening the results of quantitative data.

\section{Findings and Discussion}

Findings

Social Implication of Physics

Table 2. Social Implication of Physics

\begin{tabular}{llcc}
\hline & Classification & & $\%$ \\
\cline { 1 - 3 } Range & Attitude & Total & \\
\hline $5-8$ & Very Bad & 1 & 0.1 \\
$9-12$ & Bad & 19 & 2.1 \\
$13-16$ & Fair & 218 & 23.5 \\
$17-20$ & Good & 475 & 51.3 \\
$21-25$ & Very Good & 213 & 23.0 \\
\hline & Total & 926 & $100 \%$ \\
\hline
\end{tabular}

The social implication indicator of state senior high school students towards Physics is described in Table 2. In Table 2, there are $54.3 \%$ of students in the good category with a maximal score from the whole statements at indicator 1 is 25 . It shows that most of the students admit that there is a social implication of Physics towards their 
social life. Then, $23.5 \%$ of the students are in the fair category, which means the students are still confused about the existence of Physics science role in advance technology. Meanwhile, $2.2 \%$ students are at bad category which shows that they do not understand about the existence of good implication of Physics in their social life.

\section{Attitude towards Investigation in Physics}

The results of data analysis on the attitude towards investigation in Physics can be seen in Table 3. Table 3 also shows that the attitude towards investigation in Physics categorized into very bad is $2 \%$. Meanwhile, the attitude at bad category is $3.7 \%$, and attitude at fair category is $45 \%$. Then, $46 \%$ is in a very good category, and the last very bad attitude is at $5.1 \%$. The attitude towards investigation in Physics has a better attitude in learning Physics compared to other categories.

Table 3. Attitude towards Investigation in Physics

\begin{tabular}{|c|c|c|c|}
\hline \multicolumn{3}{|c|}{ Classification } & \multirow[t]{2}{*}{$\%$} \\
\hline Range & Attitude & Total & \\
\hline $9-16.2$ & Very Bad & 2 & $2 \%$ \\
\hline $16.3-23.5$ & $\mathrm{Bad}$ & 34 & $3.7 \%$ \\
\hline $23.6-30.8$ & Fair & 417 & $45 \%$ \\
\hline $30.9-38.1$ & Good & 426 & $46 \%$ \\
\hline $38.2-45.5$ & Very Good & 47 & $5.1 \%$ \\
\hline \multicolumn{2}{|c|}{ Total } & 926 & $100 \%$ \\
\hline
\end{tabular}

\section{Adoption of Scientific Attitude}

Table 4. Adoption of Scientific Attitude

\begin{tabular}{|c|c|c|c|}
\hline \multicolumn{3}{|c|}{ Classification } & \multirow{2}{*}{$\%$} \\
\hline Range & Attitude & Total & \\
\hline $7-12.6$ & Very Bad & 1 & $0.1 \%$ \\
\hline $12.7-18.3$ & $\mathrm{Bad}$ & 5 & $0.5 \%$ \\
\hline $18.4-24$ & Fair & 338 & $36.5 \%$ \\
\hline $25-30.6$ & Good & 519 & $56 \%$ \\
\hline $30.7-36.3$ & Very Bad & 63 & $6.8 \%$ \\
\hline \multicolumn{2}{|c|}{ Total } & 926 & $100 \%$ \\
\hline
\end{tabular}

The results of score data analysis on scientific attitude is presented in Table 4. In Table 4, it can be seen the data of questionnaires which have been processed by using SPSS program obtained from 926 respond- ents from senior high school educational level which more focus on the indicator adoption of scientific attitude. The results show that the most dominant category is good $(56 \%)$, then followed by fair $(36.5 \%)$, very $\operatorname{good}(6.8 \%)$, bad $(0.5 \%)$, and the least is really bad $(0.1 \%)$.

\section{The Interest to Extend the Duration of Learning Physics}

The results of score data analysis on the interest to extend the amount of time for learning Physics is presented in Table 5. Based on Table 5, it shows that the interest to extend the amount of time for learning Physics at very good category is $3.9 \%$, while at good category is $22 \%$, the fair category is $57.9 \%$, bad category $14.3 \%$, and the last ver bad category is $1.9 \%$. The most dominant attitude at category the interest to extend the amount of time for learning Physics is a fair attitude.

Table 5. The Interest to Extend the Amount of Time for Learning Physics

\begin{tabular}{|c|c|c|c|}
\hline \multicolumn{3}{|c|}{ Classification } & \multirow{2}{*}{$\%$} \\
\hline Range & Attitude & Total & \\
\hline $8-14.4$ & Very Bad & 18 & $1.9 \%$ \\
\hline $14.5-20.9$ & $\mathrm{Bad}$ & 132 & $14.3 \%$ \\
\hline $30-36.4$ & Fair & 536 & $57.9 \%$ \\
\hline $36.5-42.9$ & Good & 204 & $22 \%$ \\
\hline $43-49.4$ & Very Good & 36 & $3.9 \%$ \\
\hline \multicolumn{2}{|c|}{ Total } & 926 & $100 \%$ \\
\hline
\end{tabular}

The Problem Faced in Improving Students' Attitude in Batanghari Regency

Table 6. The Problem Faced in Improving Students' Attitude in Batanghari Regency

\begin{tabular}{lc}
\hline \multicolumn{1}{c}{ Indicators } & $\begin{array}{c}\text { Respondents } \\
(926)\end{array}$ \\
\hline Social implication of Physics & $2.2 \%$ \\
Attitude towards investigation in & $3.9 \%$ \\
Physics & $(36)$ \\
Adoption of scientific attitude & $0.6 \%$ \\
The interest in extending the a- & $(6)$ \\
mount of time for learning Physics & $(16.2 \%$ \\
\hline
\end{tabular}


The problem faced in improving students' attitude in Batanghari Regency is obtained at the indicator of Physics social implication, the normality of science, happiness in learning Physics and the interest to extend the time for learning Physics. These can be seen in Table 6.

From the results that have been obtained from the respondents who had filled in the questionnaires spread by the researchers, the researchers obtained four obstacles encountered by the students related to their attitude towards Physics learning (Table 6): Social Implication of Physics (2.2\%), Attitude towards investigation in Physics (3.9\%), Adoption of Scientific Attitude (0.6\%), Interest in Expanding Time for Learning Physics $(16.2 \%)$.

\section{Discussion}

Attitude comes from someone's feeling towards an object which is reflected in the feeling of like or dislike. Attitude can be observed in the learning process, perseverance, and also consistency towards an object (Basuki \& Hariyanto, 2014). Good learning result is influenced by students' positive attitude. Veloo et al. (2015) believe that the students who have a positive attitude towards learning can improve their achievement. Complicated Physics learning causes the students to have less interest in learning Physics. Yara (2009) states "The attitude towards science or Physics shows interest or feeling towards knowledge, in which the feeling meant here is the disposition of the students towards like or dislike science." Therefore, noticing students' attitude during the learning process can increase either the learning result or achievement of students. The following is the exploration of indicators used to recognize students' attitude towards Physics.

\section{Social Implication of Physics}

The results of questionnaires' data analysis on indicator social implication of Physics at senior high school in Batanghari Regency, it shows dominant students at the good category with a percentage in the a- mount of $51.3 \%$. The results of the interview show that although Physics is complicated, they realize that the concept and formula of Physics can be applied in daily lives. The concept and principles of Physics are mostly applied in life and contribute a lot in life nowadays (Veloo et al., 2015). The students who respect the roles of Physics in daily life are the students with good achievement in Physics at Senior High School, talented in science and Mathematics. Kaniawati et al. (2016) explain the concept which has important roles in learning as the foundation in learning the natural phenomenon. Until in nurturing the concept, it is better to correlate the learning to daily life problems so that the students recognize the importance of learning Physics.

\section{Attitude towards Investigation in Physics}

The results of data analysis on indicator the attitude towards the investigation in Physics at senior high school in Batanghari Regency show students' dominant attitude is at category fair with the percentage of $45 \%$. Based on the results of the interview, the students at good category have an active attitude in finding the things opposed to the results of the experiment then the students respond critically, having high curiosity, and never give up. The students who have a good attitude like experimental activities which indicates that they love to think critically, finding new interesting things in Physics through investigation they conduct. Civelek, Ucar, Ustunel, and Aydin (2014, p. 566) explain that one of the hindrances in Physics learning process is the students lack scientific thinking skill towards the science of Physics based on the concepts in learning abstract things.

By experimenting, the abstract science of Physics becomes easier to comprehended and liked by the students. Moeed (2013, p. 539) states that, through experiment, the students can develop their ability to think critically and to obtain the conclusion, step by step is required and must follow the scientific method. Experimental activities conducted can increase the activeness and self- 
confidence of the students either in experimenting or in learning activities. Stefan and Ciomos (2010, p. 8) assert that the improvement of investigation activity is influenced by self-confidence towards their own ability (the students) in learning science. This experimental activity can also improve students' curiosity; it can be seen through the students love to ask and search for a solution when doing the investigation. The form of appreciation and support for students' scientific investigation is by showing them respect scientifically by collecting, thinking creatively, thinking rationally, responding critically, communicating, and taking conclusion because they face life situation related to science (Bybee et al., 2009).

\section{Adoption of Scientific Attitude}

Based on the results of data analysis of the questionnaires at senior high school in Batanghari Regency on scientific attitude, the most dominant attitude is at the good category with the percentage in the amount of $56 \%$. Thus, it can be said generally that students' scientific attitude at senior high school in Batanghari Regency is categorized into positive. The results of the interview on the students categorized into the good category. It is recognized that they like different opinions in the class. If there is a different opinion in solving the problem, for instance, in conducting discussion, they can obtain some solution to overcome it until the students do not only focus on one solution only.

The students who have a good attitude towards scientific attitude can think objectively. Olasehinde and Olatoye (2014) stress that scientific attitude is the ability to behave consistently, rationally, and objectively in solving the problem. And the students' willingness to solve the problem occurs in the learning process can improve scientific attitude. Osborne, Shirley, and Collins (2013) assert that "Scientific attitude is the desire to know and understand, searching for verification and questioning in science." The students who have dominant attitude seen during the learning process becomes the center of attention of the teachers and becomes more active. Mukhopadhyay (2014) explains that scientific attitude is one of the main fields which becomes the attention of a teacher in a class situation in general. A good scientific attitude will help the students to improve their learning achievement. Further, Olasehinde and Olatoye (2014) add that the better the students' scientific achievement, the better their attitude towards science.

\section{The Interest in Extending the Time for Learning} Physics

From the results of data analysis on the questionnaires about the indicator of the interest in extending the time for learning Physics at senior high school in Batanghari Regency, it is clear that students' dominant attitude is at the fair category with percentage $57 \%$. The category of students' attitude at that indicator proves that only a part of students is interested in extending the time for learning Physics. Based on the results of the interview on the students at the fair category, it is recognized that when they finished school time, they learn Physics at home individually or in a group and ask their friends about the topics that they do not understand yet.

In order to improve students interest in extending the time for learning Physics, it requires students' positive attitude and students' love for the learning process. Osman et al. (2007) state that the students will feel interested and happy in learning a certain subject if they like that subject. The interest in spending time for learning Physics is important because the interest or talent in learning Physics can make the students serious in learning Physics. Students' interest in science learning at school is pivotal in continuing education to the next level. Highly positive attitude towards the interest in extending the time for learning Physics will influence learning achievement. Bybee et al. (2009) argue that the students who are interested in extending the time for learning Physics will affect their achievement and learning results in Physics. 


\section{Hindrances}

Based on the results of data analysis, there are some hindrances on each indicator. At indicator social implication of Physics, the results of analysis obtained are; 22 students or $2.2 \%$ out of 926 students have attitude at bad category. Students' attitude at bad category is because they do not think that Physics is something complicated and abstract until it is difficult for them to solve the problem related to Physics. At the attitude towards the investigation in Physics, there are 36 students at percentage $3.9 \%$ out of 926 students in bad attitude category. The hindrance encountered by the students is that they do not know how to conduct an experiment and less active when the activity is happening. Their less activity and incapability of experimenting is because they do not like Physics and consider Physics as a difficult subject.

At the indicator of adoption of scientific attitude, six students with a percentage of $0.6 \%$ out of 926 students were categorized having a bad attitude. This bad attitude is seen in learning; the students lack curiosity and thinking critically. On the indicator of the interest in extending the time for learning Physics, 177 students or $16.2 \%$ out of 926 students have a bad category. The hindrance occurred in this indicator is because the students do not really understand the topics, and they consider that Physics is difficult until they do not have interest in extending the time for learning Physics.

\section{Conclusion}

Based on the results of the research, it can be concluded that the indicator social implication of Physics and adoption of scientific attitude have good results. Meanwhile, the attitude towards investigation in Physics and interest to extend the time for learning Physics have sufficient results. The average students have a good attitude on the indicator of social implication and adoption of scientific attitude. It is because there is a relevant correlation between these two indicators. If the students feel the implication of
Physics towards their social life, then they will have a high scientific attitude. However, in general, not all students feel the implication of Physics in their social life, as a consequence, they do not like the life pattern of a scientist who always conducts investigation towards Physics, and they are not interested in extending the time for learning Physics.

Therefore, the teachers need to recognize how students behave during the learning process and fix the learning design in the class in line with students' ability. Based on the explanation on the hindrance that occurred on the indicators of students' attitude, it can be seen that the students have a bad attitude because the model or the teaching strategies of the teacher cannot improve students' positive attitude towards Physics. The learning method which provides an integrated learning environment with laboratory measurement can help the students to solve the problem in Physics and increase their attitude to be more critical. Beside the teaching method which can increase students positive attitude, the teacher must conduct learning by using science skill. The students who have science skill will cause them to have a positive attitude towards science. Improving students' scientific attitude also can increase students' positive attitude towards the learning of science or Physics.

\section{References}

Agunbiade, E., Ngcoza, K., Jawahar, K., \& Sewry, J. (2017). An exploratory study of the relationship between learners' attitudes towards learning science and characteristics of an afterschool science club. African Journal of Research in Mathematics, Science and Technology Education, 21(3), 271-281. https://doi. org/10.1080/18117295.2017.1369274

Ali, K., Shafqat, Shah, A., Makhdoom, S., Mahmood, Z., \& Zareen, R. (2012). Scientific attitude development at secondary school level: A comparison between methods of teaching. Language in India, 12(9), 439-454. 
Basuki, I., \& Hariyanto. (2014). Asesmen belajar. Bandung: Remaja Rosdakarya.

Bybee, R., McCrae, B., \& Laurie, R. (2009). PISA 2006: An assessment of scientific literacy. Journal of Research in Science Teaching, 46(8), 865-883. https://doi.org/10.1002/tea.20333

Chiappetta, E., Koballa, T., \& Collette, A. (1998). Science instruction in the middle ande secondary schools (Prentice $\mathrm{H}$ ). Upper Saddle River, NJ.

Civelek, T., Ucar, E., Ustunel, H., \& Aydin, M. K. (2014). Effects of a haptic augmented simulation on K-12 students' achievement and their attitudes towards physics. Eurasia Journal of Mathematics, Science and Technology Education, 10(6), 565-574. https://doi.org/10.12973/eurasia.201 $4.1122 \mathrm{a}$

Cohen, L., Manion, L., \& Morrison, K. (2007). Research methods in education (6th ed.). London and New York, NY: Routledge Falmer.

Creswell, J. W. (2012). Educational research: Planning, conducting, and evaluating quantitative and qualitative research (4th ed.). Boston, MA: Pearson.

Erdemir, N. (2009). Determining students' attitude towards physics through problem-solving strategy. Asia-Pacific Forum on Science Learning and Teaching, 10(2), 1-19.

Fatonah, S. (2014). Pembelajaran sains. Yogyakarta: Ombak.

Guido, R. M. (2013). Attitude and motivation towards learning physics. International Journal of Engineering Research \& Technology, 2(11), 20872094. https://doi.org/10.1093/nar/ gkn1085

Iwan, N., \& Sani, R. A. (2015). Efek model pembelajaran kooperatif tipe group investigation dan teamwork skills terhadap hasil belajar fisika. Jurnal Pendidikan Fisika, 4(1), 3.
Kaniawati, I., Samsudin, A., Hasopa, Y., Sutrisno, A. D., \& Suhendi, E. (2016). The influence of using momentum and impulse computer simulation to senior high school students' concept mastery. Journal of Physics: Conference Series, 739(1), 1-4. https://doi.org/ 10.1088/1742-6596/739/1/012060

Law of Republic of Indonesia No. 20 of 2003 on National Education System (2003).

Lederman, N. G., Lederman, J. S., \& Antink, A. (2013). Nature of science and scientific inquiry as contexts for the learning of science and achievement of scientific literacy. International Journal of Education in Mathematics, Science and Technology, 1(3), 138-147.

Martin, B., \& Briggs, L. J. (1986). The affective and cognitive domains: Integration for instruction and research. Englewood Cliffs, NJ: Educational Technology.

Moeed, A. (2013). Science investigation that best supports student learning: Teachers understanding of science investigation. International Journal of Environmental and Science Education, 8(4), 537-559. https://doi.org/10.12973/ ijese.2013.218a

Mukhopadhyay, R. (2014). Scientific attitude - Some psychometric considerations. Iosr Journal Of Humanities And Social Science (Iosr-Jhss) Osr-Jhss, 19, 98-100.

Nordin, A., \& Ling, L. H. (2011). Hubungan sikap terhadap mata pelajaran sains dengan penguasaan konsep asas sains pelajar tingkatan dua. Journal of Science \& Mathematics Educational, 2(June), 89101.

Olasehinde, K. J., \& Olatoye, R. A. (2014). Scientific attitude, attitude to science and science achievement of senior secondary school students in Katsina State, Nigeria. Journal of Educational and Social Research, 4(1), 445-452. https://doi.org/10.5901/jesr.2014.v4 n1p445 
Osborne, J., Shirley, S., \& Collins, S. (2013). Attitudes towards science: A review of the literature and its implications. International Journal of Science Education, 25(9), 37-41. https://doi.org/10. 1080/0950069032000032199

Osman, K., Iksan, Z. H., \& Halim, L. (2007). Sikap terhadap sains dan sikap saintifik di kalangan pelajar sains. Saintifike Jurnal Pendidikan, 32, 39-60.

Pitafi, A. I., \& Farooq, M. (2012). Measurement of scientific attitude of secondary school students in Pakistan. Academic Rearch International, 2(2), 379_ 392. https://doi.org/10.1002/mrm.2 4433

Riscaputantri, A., \& Wening, S. (2018). Pengembangan instrumen penilaian afektif siswa kelas IV sekolah dasar di Kabupaten Klaten. Jurnal Penelitian Dan Evaluasi Pendidikan, 22(2), 231242. https://doi.org/10.21831/pep. v22i2.16885

Stefan, M., \& Ciomos, F. (2010). The 8th and 9th grade students' attitude towards teaching and learning physics. Acta Didactica Napocensia, 3(3), 7-14.

Veloo, A., Nor, R., \& Khalid, R. (2015). Attitude towards physics and additional mathematics achievement towards physics achievement. International Education Studies, 8(3), 3543. https://doi.org/10.5539/ies.v8n3 p35
Visser, Y. L. (2007). Convergence and divergence in children's attitudes toward the sciences and science education. Boca Raton, FL: Learning Development Institute, Florida Atlantic University.

Welch, A. G. (2010). Using the TOSRA to assess high school students' attitudes toward science after competing in the first robotics competition: An exploratory study. Eurasia Journal of Mathematics, Science and Technology Education, 6(3), 187-197. https:// doi.org/10.12973/ejmste/75239

Wood, K. (2011). Education is basic. New York, NY: Taylor \& Francis.

Yance, R. D., Ramli, E., \& Mufit, F. (2013). Pengaruh penerapan model project based learning (PBL) terhadap hasil belajar fisika siswa kelas XI IPA SMA Negeri 1 Batipuh Kabupaten Tanah Datar. Pillar of Physics Education, 1(1), 48-54. Retrieved from http://e journal.unp.ac.id/students/index.php /pfis/article/view/490/279

Yara, P. O. (2009). Relationship between teachers' attitude and students' academic achievement in mathematics in some selected senior secondary schools in southwestern Nigeria. European Journal of Social Sciences, 11(3), 364-369. 